DOI https://doi.org/10.15589/znp2020.1(479).15 УДК 338.2

\title{
DIAGNOSTICS OF THE STATE OF EFFICIENCY ON THE EXAMPLE OF PJSC "KOBELIATSKYI PLANT OF FOOD PRODUCTS «MRIYA»"
}

\section{ДІАГНОСТИКА СТАНУ ЕФЕКТИВНОСТІ НА ПРИКЛАДІ ПРАТ «КОБЕЛЯЦЬКИЙ ЗАВОД ПРОДОВОЛЬЧИХ ТОВАРІВ “МРІЯ”»}

\author{
Kseniia V. Chichulina \\ Chichulinak@ukr.net \\ ORCID: 0000-0001-7448-0180
}

\author{
К. В. Чичуліна, \\ канд. техн. наук, доцент
}

\author{
National University "Yuri Kondratyuk Poltava Polytechnic", Poltava \\ Національний університет «Полтавська політехніка імені Юрія Кондратюка», м. Полтава
}

\begin{abstract}
In modern conditions, the complicated nature of the company's activities requires improvement of management tools, and especially methods of research and evaluation of their activities. As a result, it became necessary to use such a tool as economic diagnostics, which makes it possible to conduct a detailed study, get complete and truthful information about the company's activities. This would make it possible to make more effective management decisions. In the process of managing the production and economic activities of the enterprise, the use of economic diagnostics will allow you to identify the state of the enterprise on indirect grounds in time. Today, considering the problems of efficiency, there is no generally accepted approach, both by definition and by conducting diagnostics of the efficiency of economic activities of organizations and enterprises in any sphere. Such diagnostics should take into account various characteristics of successful business conduct and represent indicators of various types of evaluation. Taking this into account, the issue of determining and conducting effective diagnostics of enterprises is particularly relevant. The purpose of this work is to conduct diagnostics of PJSC "Kobeliatskyi plant of food products «Mriya»", to determine the theoretical and methodological aspects of its implementation, and to develop program measures to improve its effectiveness. The object of the work is the economic activity of PJSC "Kobeliatskyi plant of food products «Mriya»". The subject is the process of economic activity of PJSC "Kobeliatskyi plant of food products «Mriya»" and the development of its efficiency program. In the course of the study formulated the following objectives, in particular to determine the theoretical basis of the diagnosis; identify and analyze current approaches to diagnostics research companies; develop a program to improve the efficiency of economic activities of PJSC "Kobeliatskyi plant of food products «Mriya»" based on the diagnosis. The article uses methods of theoretical generalization, system and financial analysis, and diagnostics of the financial state of performance by type of economic activity.
\end{abstract}

Key words: diagnostics; efficiency; economic activity; company.

Анотація. У сучасних умовах ускладнений характер діяльності підприємства вимагає покращення інструментів управління, а особливо методів дослідження й оцінки їх діяльності, результатом чого стало необхідним застосувати такий інструмент, як економічна діагностика, який дає змогу проводити детальне дослідження, одержувати повну і правдиву інформацію про діяльність підприємства. Це дало б змогу приймати більш ефективні управлінські рішення. У процесі керування виробничо-господарською діяльністю підприємства застосування економічної діагностики дасть змогу вчасно виявити стан підприємства за непрямими ознаками. Нині немає загальноприйнятого підходу як щодо визначення, так і щодо проведення діагностики ефективності господарської діяльності організацій і підприємств будь-якої сфери. Така діагностика має враховувати різноманітні характеристики успішного ведення бізнесу і представляти показники різних видів оцінювання. 3 огляду на це особливо актуальним $є$ питання визначення та проведення ефективної діагностики підприємств. Метою роботи є проведення діагностики ПрАТ «Кобеляцький завод продовольчих товарів “Мрія”», визначення теоретичних та методичних аспектів ії̈ проведення, розробка програмних заходів із підвищення іiі ефективності. Об’єктом роботи є господарська діяльність ПрАТ «Кобеляцький завод продовольчих товарів “Мрія”». Предметом виступає процес господарської діяльності ПрАТ «Кобеляцький завод продовольчих товарів “Мрія”» та розробка програми ії ефективності. В процесі проведеного дослідження сформульовані завдання, зокрема, визначити теоретичні основи діагностики, визначити та проаналізувати сучасні підходи до проведення діагностики діяльності дослідного товариства, сформувати програму підвищення ефективності господарської діяльності ПрАТ «Кобеляцький завод продовольчих товарів “Мрія”» на основі проведеної діагностики. У статті застосовані методи теоретичного узагальнення, системного та фінансового аналізу, діагностики стану фінансової результативності за видами господарської діяльності.

Ключові слова: діагностика; ефективність; господарська діяльність; товариство. 


\section{ПОСТАНОВКА ЗАДАЧІ}

У сучасних умовах ускладнений характер діяльності підприємства вимагає покращення інструментів управління, а особливо методів дослідження й оцінки їх діяльності, результатом чого стало необхідним застосувати такий інструмент, як економічна діагностика, який дає змогу проводити детальне дослідження, одержувати повну і правдиву інформацію про діяльність підприємства. Це дало б змогу приймати більш ефективні управлінські рішення. У процесі керування виробничо-господарською діяльністю підприємства застосування економічної діагностики дасть змогу вчасно виявити стан підприємства за непрямими ознаками. Основні задачі проведеного дослідження полягають у тому, щоб визначити теоретичні основи діагностики, визначити та проаналізувати сучасні підходи до проведення діагностики діяльності ПрАТ «Кобеляцький завод продовольчих товарів “Мрія”», сформувати програму підвищення ефективності господарської діяльності ПрАТ «Кобеляцький завод продовольчих товарів “Мрія”» на основі проведеної діагностики.

\section{АНАЛІЗ ОСТАННІХ ДОСЛІДЖЕНЬ І ПУБЛІКАЦЙ}

Питанням проведення економічної та фінансової діагностики підприємств, механізмам побудови оптимальної системи діагностики та іiі сутності присвячені праці В. В. Добровольського [1], С. М. Валявського, В. В. Скриль [2], Т. А. Городні, Н. В. Білущак [3], Т. М. Ковальчук, А. І. Вергун [4], В. В. Краснової, В. Н. Ямшанова [5], Г. М. Сидоренко-Мельник [6], Л. С. Туркомана [7]. Також питання пошуку та оцінки ефективності діяльності підприємств представлені в роботах Л. Г. Мельника [8], Ю. В. Ушкаренко, М. О. Шульги [9] та інших провідних вчених-економістів.

\section{ВІДОКРЕМЛЕННЯ НЕ ВИРІШЕНИХ РАНІШЕ ЧАСТИН ЗАГАЛЬНОЇ ПРОБЛЕМИ}

У межах теорій ефективності є проблема відсутності загальноприйнятого підходу, як щодо визначення, так і щодо проведення діагностики ефективності господарської діяльності підприємств, яка має враховувати різні аспекти функціонування бізнесу й охоплювати показники як поточної, так і динамічної оцінки. 3 огляду на це питання визначення та проведення ефективної діагностики є актуальним. Актуальність та недостатня інформаційна основа зазначеної проблеми, iї теоретичне та практичне значення зумовили необхідність проведення цього дослідження, визначили його мету.

\section{МЕТА ДОСЛІДЖЕННЯ}

Мета дослідження полягає в проведенні діагностики ПрАТ «Кобеляцький завод продовольчих товарів “Мрія"», визначенні теоретичних та методичних аспектів ії проведення, розробці програмних заходів із підвищення її ефективності.

\section{МЕТОДИ, ОБ'ЄКТ ТА ПРЕДМЕТ ДОСЛІДЖЕННЯ}

У статті застосовані методи теоретичного узагальнення, системного та фінансового аналізу, діагностики стану фінансової результативності за видами господарської діяльності. Об'єктом роботи є господарська діяльність ПрАТ «Кобеляцький завод продовольчих товарів “Мрія”». Предметом виступає процес господарської діяльності ПрАТ «Кобеляцький завод продовольчих товарів “Мрія"» та розробка програми її ефективності.

\section{ОСНОВНИЙ МАТЕРІАЛ}

Для цього товариства визначення ефективності його діяльності має важливе як наукове, так і практичне значення. За їі допомогою можна не тільки оцінити ефективність роботи товариства, проаналізувати сумарний ефект різних структурних підрозділів та напрямів діяльності, а й визначити стратегію розвитку, розробити прогноз та план дій на перспективу, встановити результати використання витрачених ресурсів. На основі таблиці 1 розрахуємо показники ефективності діяльності ПрАТ «Кобеляцький завод продовольчих товарів “Мрія"» протягом 2016-2018 pр. (табл. 1). Аналізуючи розраховані показники ефективності діяльності ПрАТ «Кобеляцький завод продовольчих товарів “Мрія”» за досліджуваний період, можна зазначити, що протягом усього періоду спостерігається поступове зниження показників ефективності основної діяльності товариства. Це $є$ негативним явищем, оскільки основну масу грошових доходів підприємство отримує від основної діяльності, при цьому покриваючи адміністративні витрати, витрати на збут, інші операційні витрати та інші незначні. Ефективність фінансової діяльності протягом трьох аналізованих років знаходиться на нульовому рівні, і це не призводить до зміни розміру та складу власного і позикового капіталу. Інша операційна діяльність ПрАТ «Кобеляцький завод продовольчих товарів “Мрія"» не $є$ прибутковою, і як вже зазначалося, витрати на проведення цієї діяльності покриває основна діяльність.

Отже, у 2018 р. відбулося погіршення ефективності діяльності товариства, адже саме від основної та фінансової діяльності мають бути найбільші суми доходів. Про це також свідчать показники ефективності звичайної діяльності, які є підсумком показників ефективності основної, іншої операційної, фінансової діяльності товариства, і вони мали високі значення у 2016 р., у наступних роках відбувалося їх зниження, у середньому на $47 \%$ кожного року.

Варто зазначити, що діяльність товариства не є збитковою, але таке стрімке зниження показників ефективності діяльності товариства $\epsilon$ ризиковим і може мати негативні наслідки в майбутньому.

Спираючись на методику оцінки показників фінансової ефективностіза видами діяльностіпідприємства, 
яка представлена в таблиці 2 та критерії діагностики стану ефективності діяльності товариства, що наведені в таблиці 2, продіагностуємо фінансову ефективність за кожним із видів діяльності ПрАТ «Кобеляцький завод продовольчих товарів “Мрія”» за 2016-2018 pp.

Як можемо спостерігати, показники фінансової ефективності ПрАТ «Кобеляцький завод продовольчих товарів “Мрія”» набувають високого значення за основною діяльністю, що, зрештою, визначає оптимальний стан фінансової ефективності звичайної діяльності підприємства. Поряд iз тим чітко видно негативні тенденції наявності від'ємних значень фінансової ефективності за підсумками іншої операційної діяльності та нульових значень за підсумками фінансової діяльності, що визначають стан фінансової ефективності іншої операційної та фінансової діяльності як кризовий та середній відповідно.

Проаналізуємо стан фінансової ефективності за видами господарської діяльності ПрАТ «Кобеляць- кий завод продовольчих товарів “Мрія”» за 2017 р. (табл. 3).

Показники фінансової ефективності за основною діяльністю набувають високих значень. Підвищились показники фінансової ефективності за підсумками іншої операційної діяльності порівняно з попереднім роком і визначили стан фінансової ефективності як нестійкий. Залишився незмінним середній стан фінансової ефективності за підсумками фінансової діяльності. Як підсумок стан фінансової ефективності звичайної діяльності товариства характеризується високими показниками і визначається як оптимальний.

Представимо таблицю 4, зокрема показники фінансової ефективності ПрАТ «Кобеляцький завод продовольчих товарів “Мрія”» у 2018 р.

Зазначимо, що показники фінансової ефективності набувають високого значення за основною діяльністю, при цьому порівнюючи ці значення з показниками за попередні роки (табл. 2-3) спостерігаємо негативну спадаючу тенденцію. Проте, як і в 2017 р., незмінними залишились негативні тенденції наяв-

Таблиця 1. Показники ефективності діяльності ПрАТ «Кобеляцький завод продовольчих товарів “Мрія”» протягом 2016-2018 pp.

\begin{tabular}{|c|c|c|c|c|c|c|c|c|c|}
\hline \multirow{3}{*}{ Вид діяльності } & \multicolumn{9}{|c|}{ Формула розрахунку показника } \\
\hline & \multicolumn{3}{|c|}{$\begin{array}{c}\text { Фінансова ефективність } \\
\text { активів (ФЕа), \% }\end{array}$} & \multicolumn{3}{|c|}{$\begin{array}{c}\text { Фінансова ефективність } \\
\text { власного капіталу (ФЕвк), \% }\end{array}$} & \multicolumn{3}{|c|}{$\begin{array}{c}\text { Фінансова ефективність } \\
\text { інвестицій (ФЕі), \% }\end{array}$} \\
\hline & 2016 & 2017 & 2018 & 2016 & 2017 & 2018 & 2016 & 2017 & 2018 \\
\hline $\mathbf{A}$ & 1 & 2 & 3 & 4 & 5 & 6 & 7 & 8 & 9 \\
\hline Основна діяльність & 29,99 & 16,13 & 10,35 & 33,30 & 17,66 & 11,22 & 411,76 & 223,38 & 219,21 \\
\hline $\begin{array}{c}\text { Інша операційна } \\
\text { діяльність }\end{array}$ & $-8,24$ & $-2,52$ & $-2,74$ & $-9,15$ & $-2,76$ & $-2,97$ & $-85,76$ & $-22,77$ & $-32,38$ \\
\hline $\begin{array}{l}\text { Фінансова } \\
\text { діяльність }\end{array}$ & 0 & 0 & 0 & 0 & 0 & 0 & 0 & 0 & 0 \\
\hline Звичайна діяльність & 21,75 & 13,61 & 7,61 & 24,15 & 14,90 & 8,25 & 326,19 & 200,61 & 186,83 \\
\hline
\end{tabular}

Таблиця 2. Діагностика стану фінансової ефективності за видами господарської діяльності ПрАТ «Кобеляцький завод продовольчих товарів “Мрія”» у 2016 р.

\begin{tabular}{|c|c|c|c|c|c|}
\hline $\begin{array}{c}\text { Рівень } \\
\text { показника }\end{array}$ & \multicolumn{4}{|c|}{ Вид господарської діяльності } & $\begin{array}{c}\text { Рівень } \\
\text { показника }\end{array}$ \\
\hline ФЕа, \% & основна & інша операційна & фінансова & $\begin{array}{c}\text { звичайна до } \\
\text { оподаткування }\end{array}$ & ФЕвк, \% \\
\hline $\begin{array}{l}\text { Високий } \\
\text { ФЕа > } 5\end{array}$ & $\begin{array}{c}\text { ФЕа=29,99 } \\
\text { ФЕвк }=29,73 \\
\text { Оптимальний стан }\end{array}$ & & & $\begin{array}{c}\Phi Е \mathrm{E}=21,75 \\
\Phi Е в \kappa=24,15 \\
\text { Оптимальний стан }\end{array}$ & $\begin{array}{c}\text { Високий } \\
\text { ФЕвк > } 10\end{array}$ \\
\hline $\begin{array}{l}\text { Середній } \\
0 \leq \Phi Е а<5\end{array}$ & & & $\begin{array}{c}\Phi Е а=0 \\
\text { ФЕвк }=0 \\
\text { Середній стан }\end{array}$ & & $\begin{array}{c}\text { Середній } \\
0 \leq \text { Евк }<10\end{array}$ \\
\hline $\begin{array}{l}\text { Низький } \\
\text { Фа > -5 }\end{array}$ & & & & & $\begin{array}{l}\text { Низький } \\
\text { ФЕвк > - } 7\end{array}$ \\
\hline $\begin{array}{l}\text { Кризовий } \\
\Phi Е а<-5\end{array}$ & & $\begin{array}{c}\text { ФЕа= }=-8,24 \\
\text { ФЕвк= -9,15 } \\
\text { Кризовий стан }\end{array}$ & & & $\begin{array}{l}\text { Кризовий } \\
\text { ФЕвк< -7 }\end{array}$ \\
\hline
\end{tabular}


ності від'ємних значень фінансової ефективності за підсумками іншої операційної та нульових значень за підсумками фінансової діяльності. У результаті стан фінансової ефективності звичайної діяльності товариства визначається як прогресивний.

Отже, можемо зазначити, що стан фінансової ефективності господарської діяльності ПрАТ «Кобеляцький завод продовольчих товарів “Мрія”» знаходиться на середньому рівні іє прогресивним. Варто також зазначити, що відбулося зниження ефективності діяльності у 2018 р., у попередніх аналізованих роках вона знаходилась на оптимальному рівні. Показники фінансової ефективності зі звичайної діяльності, що є підсумком фінансової ефективності усіх видів господарської діяльності товариства, у 2018 р. знизились порівняно з попередніми роками. Зокрема фінансова ефективність активів має значення (7,61\%), що на 14,14\% менше ніж у 2016 р., та на 6\% ніж у 2016 р. Фінансова ефективність власного капіталу знизилась на 15,90\% та на 6,65\% відповідно щодо 2016 і 2017 pp. і становить 8,25\%. Динаміка показників фінансової ефективності зі звичайної діяльності ПрАТ «Кобеляцький завод продовольчих товарів “Мрія”» зображена на рисунку 1.

При розрахунках ефективності діяльності товариства були використані середньорічні суми активів та власного капіталу, що є одним із ключових факторів, котрі впливають на ефективність діяльності

Отже, провівши розрахунок та аналіз показників ефективності діяльності ПрАТ «Кобеляцький завод продовольчих товарів “Мрія”», зазначимо, що товариство перебуває в прогресивному стані і потребує змін та удосконалень задля досягнення оптимального стану ефективності його діяльності.

Розробляючи програму підвищення ефективності господарської діяльності ПрАТ «Кобеляцький завод продовольчих товарів “Мрія”», зазначимо, що підвищення ефективності господарської діяльності - це один із найважливіших економічних важелів у системі управління виробництвом загалом та системою внутрішньогосподарського планування, контролю та

Таблиця 3. Діагностика стану фінансової ефективності за видами господарської діяльності ПрАТ «Кобеляцький завод продовольчих товарів “Мрія”» у 2017 р.

\begin{tabular}{|c|c|c|c|c|c|}
\hline \multirow{2}{*}{$\begin{array}{c}\begin{array}{c}\text { Рівень } \\
\text { показника }\end{array} \\
\Phi Е а, \%\end{array}$} & \multicolumn{4}{|c|}{ Вид господарської діяльності } & \multirow{2}{*}{$\begin{array}{c}\begin{array}{c}\text { Рівень } \\
\text { показника }\end{array} \\
\text { ФЕвк, \% }\end{array}$} \\
\hline & основна & інша операційна & фінансова & $\begin{array}{c}\text { звичайна до } \\
\text { оподаткування }\end{array}$ & \\
\hline $\begin{array}{l}\text { Високий } \\
\text { ФЕа }>5\end{array}$ & $\begin{array}{c}\Phi Е а=16,13 \\
\text { ФЕвк }=17,66 \\
\text { Оптимальний стан }\end{array}$ & & & $\begin{array}{c}\Phi Е а=13,61 \\
\text { ФЕвк }=14,90 \\
\text { Оптимальний стан }\end{array}$ & $\begin{array}{c}\text { Високий } \\
\text { ФЕвк }>10\end{array}$ \\
\hline $\begin{array}{c}\text { Середній } \\
0<\Phi Е а<5\end{array}$ & & & $\begin{array}{c}\Phi Е а=0 \\
\Phi Е в к=0 \\
\text { Середній стан }\end{array}$ & & $\begin{array}{c}\text { Середній } \\
0<\Phi Е в к<10\end{array}$ \\
\hline $\begin{array}{l}\text { Низький } \\
\text { ФЕа > -5 }\end{array}$ & & $\begin{array}{c}\text { ФЕа = -2,52 } \\
\text { ФЕвк = -2,76 } \\
\text { Нестійкий стан }\end{array}$ & & & $\begin{array}{c}\text { Низький } \\
\text { ФЕвк > - } 7\end{array}$ \\
\hline $\begin{array}{l}\text { Кризовий } \\
\text { ФЕа }<-5\end{array}$ & & & & & $\begin{array}{l}\text { Кризовий } \\
\text { ФЕвк }<-7\end{array}$ \\
\hline
\end{tabular}

Таблиця 4. Діагностика стану фінансової ефективності за видами господарської діяльності ПрАТ «Кобеляцький завод продовольчих товарів “Мрія”» у 2018 р.

\begin{tabular}{|c|c|c|c|c|c|}
\hline $\begin{array}{c}\text { Рівень } \\
\text { показника }\end{array}$ & \multicolumn{4}{|c|}{ Вид господарської діяльності } & $\begin{array}{c}\text { Рівень } \\
\text { показника }\end{array}$ \\
\hline$\Phi E a, \%$ & основна & інша операційна & фінансова & $\begin{array}{c}\text { звичайна до } \\
\text { оподаткування }\end{array}$ & FEK, \% \\
\hline $\begin{array}{l}\text { Високий } \\
\text { Фа > } 5\end{array}$ & $\begin{array}{c}\Phi Е а=10,35 \\
\text { ФЕвк }=11,22 \\
\text { Оптимальний } \quad \text { стан }\end{array}$ & & & $\begin{array}{c}\Phi Е a=7,61 \\
\text { Оптимальний стан }\end{array}$ & $\begin{array}{c}\text { Високий } \\
\text { ФЕвк > } 10\end{array}$ \\
\hline $\begin{array}{l}\text { Середній } \\
0 \leq \Phi Е а<5\end{array}$ & & & $\begin{array}{c}\Phi Е а=0 \\
\Phi Е в к=0 \\
\text { Середній стан }\end{array}$ & $\begin{array}{c}\text { ФЕвк= 8,25 } \\
\text { Середній стан }\end{array}$ & $\begin{array}{c}\text { Середній } \\
0 \leq \text { Евк }<10\end{array}$ \\
\hline $\begin{array}{l}\text { Низький } \\
\text { Фа > -5 }\end{array}$ & & $\begin{array}{c}\text { ФЕа= -2,52 } \\
\text { ФЕвк= -2,76 } \\
\text { Нестійкий стан }\end{array}$ & & & $\begin{array}{l}\text { Низький } \\
\text { ФЕвк > - } 7\end{array}$ \\
\hline $\begin{array}{l}\text { Кризовий } \\
\text { ФЕа< -5 }\end{array}$ & & & & & $\begin{array}{l}\text { Кризовий } \\
\text { ФЕвк< }<7\end{array}$ \\
\hline
\end{tabular}


аналізу зокрема. Тому розробка заходів із підвищення ефективності виробничо-господарської діяльності є одним із головних завдань діяльності ПрАТ «Кобеляцький завод продовольчих товарів “Мрія”». Конкурентне ринкове середовище потребує від товариства постійного вдосконалення. Досягнення високого рівня конкурентоспроможності передбачає отримання низки конкурентних переваг. Основними шляхами отримання яких $є$ стати кращим самому шляхом впровадження заходів щодо удосконалення власної діяльності та підвищення іiі ефективності, безпосередньо послабити конкурентів, змінити рин-
30

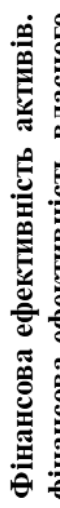

总

24,15

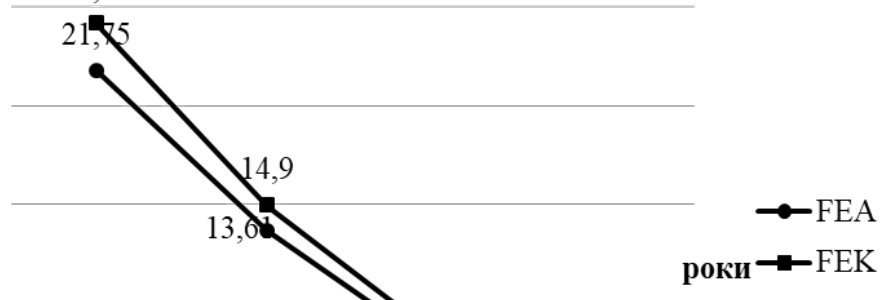

$2016 \quad 2017 \quad 2018$

Рис. 1. Динаміка показників фінансової ефективності звичайної діяльності ПрАТ «Кобеляцький завод продовольчих товарів “Мрія”» за 2016-2018 рр.

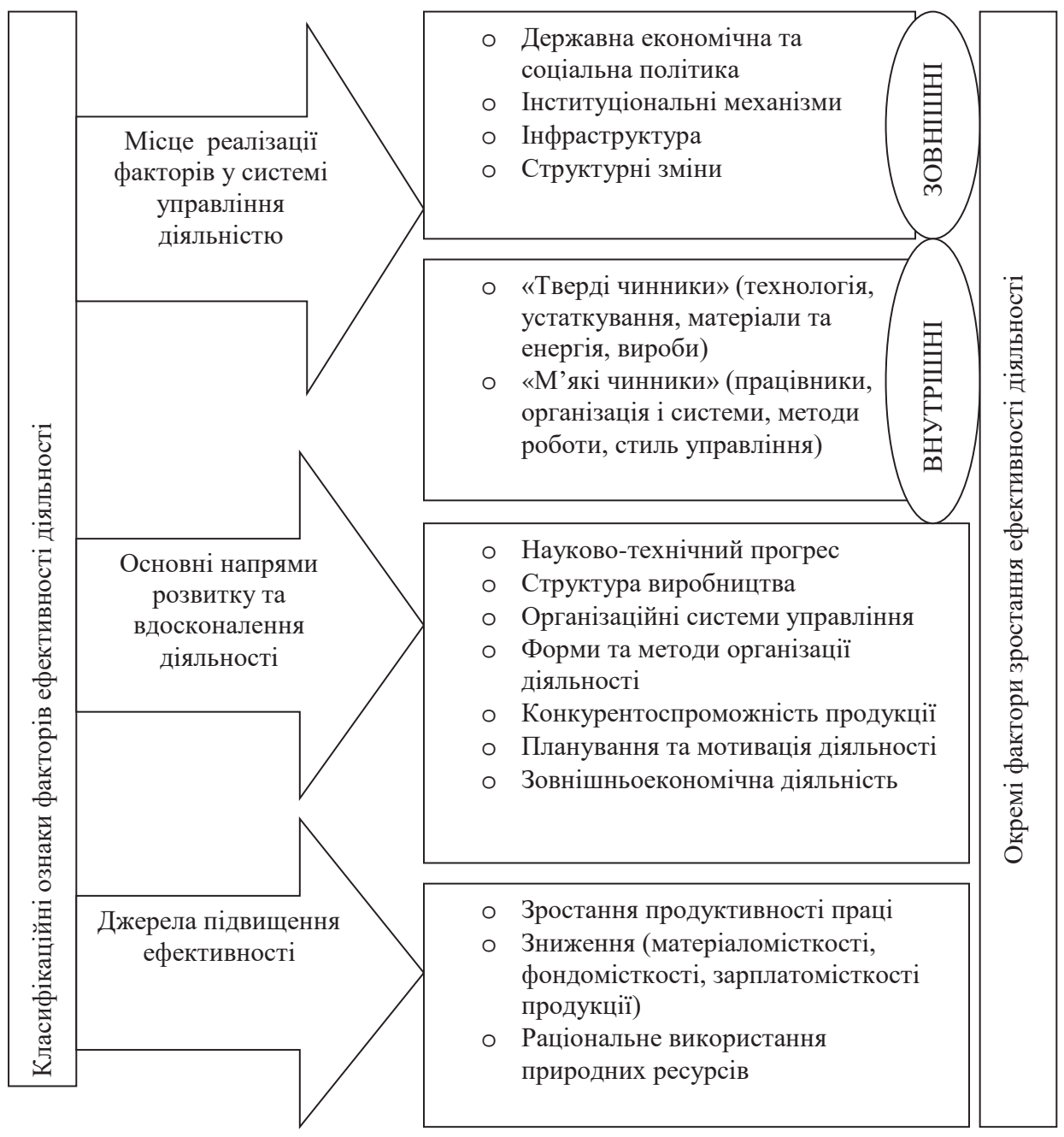

Рис. 2. Фактори впливу на ефективність діяльності ПрАТ «Кобеляцький завод продовольчих товарів "Мрія"» 
кове середовище. Оскільки реалізація останніх двох напрямів потребує значних зусиль, основним засобом отримання конкурентних переваг залишається підвищення ефективності власної діяльності.

Проведений аналіз функціонування товариства дав змогу сформувати перелік факторів, які безпосередньо здійснюють вплив на ефективність його діяльності, і згрупувати їх (рис. 2).

Досягнення максимальної результативності можливе завдяки вчасному попередженню негативних факторів, що впливають на ефективність, та стимулюванню акторів підвищення ефективності, зокрема удосконалення організаційної структури, збалансування виробничого потенціалу, впровадження нових технологій. Реалізація всіх факторів підвищення ефективності діяльності дослідного товариства забезпечить отримання значного економічного ефекту (рис. 3).

\section{ОБГОВОРЕННЯ ОТРИМАНИХ РЕЗУЛЬТАТІВ}

Отже, з огляду на результати проведеної діагностики господарської діяльності ПрАТ «Кобеляцький завод продовольчих товарів “Мрія”» товариству необхідно домогтися підвищення рентабельності, продуктивності праці, приділити увагу залученню позикових джерел фінансування та оновленню необоротних виробничих актив, передусім, шляхом підвищення ефективності виробничо-господарської діяльності. Кожен із виявлених напрямів на ефективність господарської діяльності товариства має різну ступінь впливу. Комплексне застосування вищевказаних напрямів дасть змогу не тільки покращити ефективність товариства, а і загалом його фінансово-економічну ситуацію, що є основою прибуткового функціонування, як на національному, так і на міжнародних ринках. Отже, підсумовуючи вищесказане та враховуючи проблеми та переваги, які має ПрАТ «Кобеляцький

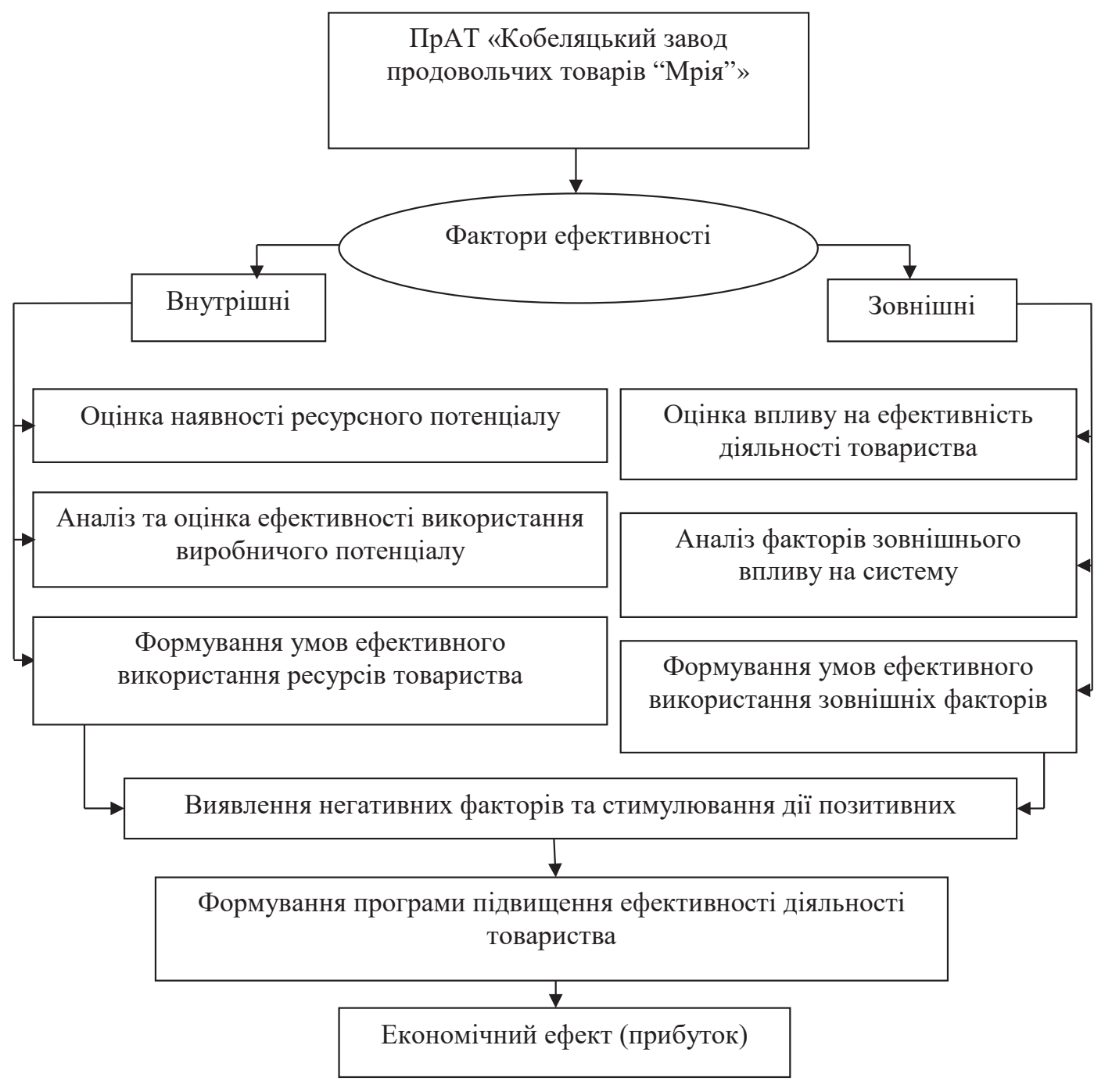

Рис. 3. Механізм реалізації програми підвищення ефективності господарської діяльності ПрАТ «Кобеляцький завод продовольчих товарів “Мрія”» 
завод продовольчих товарів “Мрія”» нині вкажемо найбільш важливі рішення для підвищення ефективності господарської діяльності товариства.

\section{ВИСНОВКИ}

У результаті проведеного дослідження були розраховані та проаналізовані показники ефективності діяльності ПрАТ «Кобеляцький завод продовольчих товарів “Мрія"» на основі запропонованого підходу до діагностики господарської діяльності товариства. Сформована програма підвищення ефективності господарської діяльності товариства, яка надалі дасть змогу оптимізувати виробничий процес та збільшити майбутні прибутки дослідного товариства.

\section{REFERENCES}

[1] Byba V. V. (2015) Diahnostyka ta prohnozuvannia finansovo-ekonomichnoho stanu pidpryiemstva [Diagnosis and prognosis of finansial and economic state enterprises]. Ekonomika ta derzhava, no. 5, pp. 110-113.

[2] Valiavskyi S. M., Skryl V. V. (2018) Diahnostyka rozvytku pidpryiemstv pyvovarnoi haluzi v umovakh mizhnarodnoi intehratsii [Diagnostics of the development of enterprises of the beef area in the conditions of Iinternational integration]. Skhidna Yevropa: Ekonomika, biznes ta upravlinnia, no. 2(13), pp. 15-25.

[3] Horodnia T. A., Bilushchak N. V. (2012) Mekhanizm provedennia ekonomichnoho diahnostuvannia diialnosti [The mechanism of economic diagnosis of activity]. Naukovyi visnyk NLTU Ukrainy, no. 22.12, pp. 337-341.

[4] Kovalchuk T. M., Verhun A. I. (2015) Diahnostychnyi analiz finansovoho stanu: teoriia ta metodolohiia [Diagnostic analysis of financial condition theory and methodology]. Visnyk Khmelnytskoho natsionalnoho universytetu, no. 5 (1), pp. 129-134.

[5] Krasnova V. V., Yamshanov V. N. (2014) Teoretychni pidkhody do vyznachennia sutnosti ekonomichnoi diahnostyky [Theoretical approaches to the definition of the essence of economic diagnostic]. Naukovyi visnyk KhDU, no. 6 (2), pp. 219-222.

[6] Sydorenko-Melnyk H. M. (2013) Rol finansovoi diahnostyky v diialnosti pidpryiemstva [The role of financial diagnosis in the enterprises activity]. Visnyk Khmelnytskoho natsionalnoho universytetu, no. 4(1), pp. 15-19.

[7] Turkoman L. S. (2019) Rol i mistse ekonomichnoi diahnostyky v systemi otsinky stanu subiektiv hospodariuvannia [The role and place of economic diagnostics in the system of assessment of the status of economic entities]. Naukovi pratsi, no. 96(109), pp. 87-97.

[8] Melnyk L. H. (2006) Teoretychni aspekty otsinky efektyvnosti diialnosti pidpryiemstva [Theoretical aspects of the enterprise performance evaluation]. $656 \mathrm{p}$.

[9] Ushkarenko Yu. V., Shulha M. O. (2016) Otsinka ekonomichnoi efektyvnosti diialnosti pidpryiemstv kharchovoi promyslovosti [Evaluation of economic efficiency of food industry enterprises of food industry enterprises]. Ekonomichnyi prostir : zbirnyk naukovykh prats, no. 111. pp. 196-207.

\section{СПИСОК ВИКОРИСТАНОЇ ЛІТЕРАТУРИ}

[1] Биба В. В. (2015) Діагностика та прогнозування фінансово-економічного стану підприємства. Економіка та держава. № 5. С. 110-113.

[2] Валявський С. М., Скриль В. В. (2018) Діагностика розвитку підприємств пивоварної галузі в умовах міжнародної інтеграції. Східна Європа: Економіка, бізнес та управління. № 2 (13). С. 15-25.

[3] Городня Т. А., Білущак Н. В. (2012) Механізм проведення економічного діагностування діяльності. Науковий вісник НЛТУ України. № 22.12. С. 337-341.

[4] Ковальчук Т. М., Вергун А. І. (2015) Діагностичний аналіз фінансового стану: теорія та методологія. Вісник Хмельницького національного університету. № 5 (1). С. 129-134.

[5] Краснова В. В., Ямшанов В. Н. (2014) Теоретичні підходи до визначення сутності економічної діагностики. Науковий вісник ХДУ. № 6 (2). С. 219-222.

[6] Сидоренко-Мельник Г. М. (2013) Роль фінансової діагностики в діяльності підприємства. Вісник Хмельницького начіонального університету. № 4 (1). С. 15-19.

[7] Туркоман Л. С. (2019) Роль і місце економічної діагностики в системі оцінки стану суб'єктів господарювання . Наукові праці. № 96(109). С. 87-97.

[8] Мельник Л. Г. (2006) Теоретичні аспекти оцінки ефективності діяльності підприємства. 656 с.

[9] Ушкаренко Ю. В., Шульга М. О. (2016) Оцінка економічної ефективності діяльності підприємств харчової промисловості. Економічний простір: збірник наукових пращъ. № 111. С. 196-207. 